\title{
Isolation and characterisation of crude oil sludge degrading bacteria
}

\author{
Linda U. Obi ${ }^{1,3}$, Harrison I. Atagana ${ }^{2}$ and Rasheed A. Adeleke ${ }^{1,3,4^{*}}$
}

*Correspondence: adeleker@
arc.agric.za
${ }^{1}$ Department
of Environmental Sciences,
University of South Africa,
Johannesburg, South Africa
Full list of author information
is available at the end of the
article

*Correspondence: adeleker@

of Environmental Sciences, University of South Africa, Johannesburg, South Africa is available at the end of the

\begin{abstract}
Background: The use of microorganisms in remediating environmental contaminants such as crude oil sludge has become a promising technique owing to its economy and the fact it is environmentally friendly. Polycyclic aromatic hydrocarbons (PAHs), as the major components of oil sludge, are hydrophobic and recalcitrant. An important way of enhancing the rate of PAH desorption is to compost crude oil sludge by incorporating commercial surfactants, thereby making them available for microbial degradation. In this study, crude oil sludge was composted for 16 weeks during which surfactants were added in the form of a solution.

Results: Molecular characterisation of the 165 rRNA genes indicated that the isolates obtained on a mineral salts medium belonged to different genera, including Stenotrophmonas, Pseudomonas, Bordetella, Brucella, Bacillus, Achromobacter, Ochrobactrum, Advenella, Mycobacterium, Mesorhizobium, Klebsiella, Pusillimonas and Raoultella. The percentage degradation rates of these isolates were estimated by measuring the absorbance of the 2,6-dichlorophenol indophenol medium. Pseudomonas emerged as the top degrader with an estimated percentage degradation rate of $73.7 \%$ after 7 days of incubation at $28^{\circ} \mathrm{C}$. In addition, the presence of the catabolic gene, catechol-2,3-dioxygenase was detected in the bacteria isolates as well as in evolutionary classifications based on phylogeny.

Conclusions: The bacteria isolated in this study are potential agents for the bioremediation of crude oil sludge.

Keywords: Bioremediation, Crude oil sludge, Polycyclic aromatic hydrocarbon (PAHs), Composting, Bacteria, 16S rRNA, Catechol-2,3-dioxygenase
\end{abstract}

\section{Background}

High demand for petroleum products all over the world has led to an increase in crude oil extraction and processing. This has resulted in an increased generation of large amounts of oily waste (Bhattacharyya and Shekdar 2003). An important example of such waste is crude oil sludge, which is a highly viscous material consisting of a mixture of oil contaminated sand (clay, silica and oxides) and the associated chemicals and water used during the refining process (Heidarzadeh et al. 2010). Crude oil sludge is mainly generated during the cleaning of storage tanks and the treatment of waste water from refineries. The constituents of crude oil sludge are toxic, mutagenic and carcinogenic and may persist in the environment for prolonged periods, posing a major threat to ecosystems

(c) The Author(s) 2016. This article is distributed under the terms of the Creative Commons Attribution 4.0 International License (http://creativecommons.org/licenses/by/4.0/), which permits unrestricted use, distribution, and reproduction in any medium, provided you give appropriate credit to the original author(s) and the source, provide a link to the Creative Commons license, and indicate if changes were made. 
(Wu et al. 2008; Ayotamuno et al. 2011; Balachandran et al. 2012; Enabulele and Obayagbona 2013). One of the major limitations of polycyclic aromatic hydrocarbons (PAHs) biodegradation is the low bioavailability of pollutants to the degrading microorganisms. The incorporation of commercially available surfactants in bioremediation techniques is thus a possible option for increasing the bioavailability of polycyclic aromatic hydrocarbons (PAHs) (Wong et al. 2004; Wyrwas et al. 2011).

The efficient disposal of crude oil sludge has become a growing concern as improper disposal results in serious environmental pollution (Loick et al. 2009). The need to remediate this contaminant has thus led to the development of certain technologies (physical and chemical) that promote the destruction, relocation, immobilisation and confinement of the oil sludge. Bioremediation is a biological approach that involves the use of microorganisms' metabolic potential to degrade pollutants into innocuous compounds (Milic et al. 2009; Hara et al. 2013; Singh and Chandra 2014). Because most constituents of crude oil sludge are biodegradable, the use of bioremediation techniques has proven to be economical, environmentally friendly and flexible (Niti et al. 2013).

Compost bioremediation is a form of bioremediation that involves adding of composting ingredients to contaminated wastes, where the compost matures in the presence of the contaminants (Antizar-Ladislao et al. 2008). Owing to the presence of a diverse microbial populations composting of oil sludge is a simple operation and results in high treatment efficiency (Antizar-Ladislao et al. 2006; Sayara et al. 2011; Badr El-Din et al. 2014).

Several studies have reported on the catabolic abilities of microorganisms such as fungi, bacteria and algae to degrade petroleum hydrocarbons (Riser-Roberts 1992; Dean-Ross et al. 2002; Bundy et al. 2004; Wang et al. 2011; Maiti et al. 2012; Ahirwar and Dehariya 2013; Badr El-Din et al. 2014); these microorganisms possess specific enzyme systems that enable them to degrade and utilise hydrocarbons as their carbon and energy sources (Panda et al. 2013). The most important means of aerobic PAH biodegradation is the primary oxidation of the aromatic benzene ring through which molecular oxygen is incorporated by the dioxygenase enzymes to form cis-dihydrodiols. The intermediates of dihydrodiol dehydrogenation are metabolised to carbon dioxide and water through the catechols by the actions of catechol dioxygenases and other enzymes (Chikere et al. 2011). The present study deals with the isolation and characterisation of the bacteria that are capable of growing in and utilising crude oil sludge as their sole source of carbon and energy during compost bioremediation of crude oil sludge. The presence of catabolic enzymes such as catechol dioxygenases was subsequently ascertained using both culture dependent and culture independent methods.

\section{Methods}

Experimental set-up

The experimental design consisted of 15 transparent laboratory scale composting bins of about $20 \mathrm{~cm} \times 40 \mathrm{~cm}$ in size, with lids. The sides and lids of the composters were perforated for aeration purposes. Each of the composting bins contained $1.5 \mathrm{~kg}$ of top soil, $300 \mathrm{~g}$ of crude oil sludge and $180 \mathrm{~g}$ of bark chips. Different proportions of soybean meal and horse manure were then added to different composters. Accordingly, $1 \mathrm{~kg}$ of soybean meal was added to the first five sets of composters; $500 \mathrm{~g}$ of soybean meal and 
$500 \mathrm{~g}$ of horse manure to the next five sets and $1 \mathrm{~kg}$ of horse manure to the last five sets. In addition, anionic and non-ionic surfactants were added to the compost matrix at different concentrations of 0.5 and 1.0\%. The compost was set up in the pot house of Agricultural Research Council-Institute for soil, Climate and Water.

\section{Sampling}

Samples were collected from the composting vessels after 16 weeks of composting, transported to the laboratory in sterile plastic containers and stored at $4{ }^{\circ} \mathrm{C}$ until they were used.

\section{Media}

Three different media were used in this study: Bushnell Haas broth consisting of $0.2 \mathrm{~g}$ $\mathrm{MgSO}_{4}, 0.02 \mathrm{~g} \mathrm{CaCl}_{2}, 1.0 \mathrm{~g} \mathrm{KHPO} 4,1.0 \mathrm{~g} \mathrm{~K}_{2} \mathrm{HPO}_{4}, 1.0 \mathrm{~g} \mathrm{NH}_{4} \mathrm{NO}_{3}, 0.05 \mathrm{~g} \mathrm{FeCl}_{3}$ per litre of distilled water, pH 7.0; a mineral salts medium consisting of $5.0 \mathrm{~g} \mathrm{NaCl}, 5.0 \mathrm{~g} \mathrm{KH}_{2} \mathrm{PO}_{4}$, $1.0 \mathrm{~g} \mathrm{~K}_{2} \mathrm{HPO}_{4}, 1.0 \mathrm{~g}\left(\mathrm{NH}_{4}\right)_{2} \mathrm{SO}_{4}, 0.25 \mathrm{~g} \mathrm{MgSO}_{4} \cdot 7 \mathrm{H}_{2} \mathrm{O}, 2.0 \mathrm{~g} \mathrm{NaNO}_{3}, 0.02 \mathrm{~g} \mathrm{FeCl}_{2} \cdot 4 \mathrm{H}_{2} \mathrm{O}$, $0.02 \mathrm{~g} \mathrm{CaCl}_{2}$ per litre of distilled water, $\mathrm{pH} 7.2$; and mineral salts agar consisting of a mineral salts medium $+12 \mathrm{~g}$ of bacteriological agar per litre of distilled water.

\section{Isolation of bacteria}

Bacteria were isolated by means of the enrichment culture technique (Liu et al. 2010, 2014). Two hundred and fifty millilitre Erlenmeyer flasks containing $100 \mathrm{ml}$ of sterile mineral salts medium, $1.5 \mathrm{~g}$ of compost samples (1.5\%) and $1 \mathrm{ml}$ of crude oil sludge (1\%) were incubated in a rotary incubator at 130 revolutions per minute (rpm) and $28{ }^{\circ} \mathrm{C}$. The control treatment did not include added compost. An aliquot of $5 \mathrm{ml}$ was sub-cultured onto a fresh mineral salts medium with $1 \%$ crude oil sludge every 21 days and incubated under the same conditions. After three transferences, a flame sterilised loop was used to streak the culture onto plates that contained mineral salts agar; these were then incubated at $28{ }^{\circ} \mathrm{C}$ for 7 days. After several sub-culturing exercises pure isolates were obtained. Pure colonies were then stored in nutrient agar slants for further characterisation.

\section{Identification and characterisation of oil sludge degrading bacterial isolates Morphological characterisation}

Pure colonies of oil sludge degrading bacteria were identified and characterised based on the results of their gram reaction tests and their morphological features when compared to Bergey's manual (Garrity et al. 2005; Cerqueira et al. 2011).

\section{Molecular characterisation}

\section{Sequence analysis of the $16 \mathrm{~S}$ rRNA gene}

Colony polymerase chain reaction (PCR) was used to amplify the target $16 \mathrm{~S}$ rRNA region of the DNA in bacterial cells. The process was performed by picking a single colony of bacteria isolates from the nutrient agar medium using the tip of a sterile pipette and placing it in $100 \mu \mathrm{l}$ of sterile distilled water in a $1.5 \mathrm{ml}$ microcentrifuge tube. The tube was incubated at between 94 and $95{ }^{\circ} \mathrm{C}$ for 10 min using a digital dry bath (Bio Rad). A volume of $2 \mu \mathrm{l}$ was used as a DNA template for the amplification reaction. The 
16S rRNA region was amplified by PCR using the forward primer, 27F (5'-AGA GTT TGA TCC TGG CTC AG-3') and reverse primer 1492R (5'-CGG CTA CCT TGT TAC GAC TT-3') (Liu et al. 2014). The amplification reaction was prepared using $10 \mu \mathrm{l}$ of $2 \times$ PCR Master Mix (Thermo Scientific Phusion Flash High-Fidelity), $1 \mu \mathrm{l}$ of each forward and reverse primer $(10 \mu \mathrm{M}), 2 \mu \mathrm{l}$ of the DNA template and $6 \mu \mathrm{l}$ of sterile distilled water resulting in a $20 \mu \mathrm{l}$ reaction volume. The negative control was set up without genomic DNA. The amplification reaction was performed in a thermal cycler (Bio $\operatorname{Rad} \mathrm{T} 100^{\mathrm{TM}}$ ) as follows: one cycle at $98{ }^{\circ} \mathrm{C}$ for $10 \mathrm{~s}$, followed by 34 cycles at $98{ }^{\circ} \mathrm{C}$ for one second, $53{ }^{\circ} \mathrm{C}$ for $1 \mathrm{~min}$ and $72{ }^{\circ} \mathrm{C}$ for $15 \mathrm{~s}$. A final extension step at $72{ }^{\circ} \mathrm{C}$ for 1 min was performed for 1 cycle. The reaction was held at $4{ }^{\circ} \mathrm{C}$ until the amplicons were removed from the thermal cycler. The amplicons were then assessed by running $1 \%$ agarose gel electrophoresis and viewed in the Gel Doc imager (Bio Rad). PCR products were sent to Inqaba Biotechnological Industries for purification and sequencing. The amplified 16S rRNA gene sequences were aligned using the Bioedit and CLUSTALW software. The Basic Local Alignment Search Tool (BLAST) program of the National Centre for Biotechnology Information (NCBI) was used to search and identify the closest species. The Mothur 1.25.1 software program was then used to cluster similar sequences into OTUs (operational taxonomic units). Finally, Simpsons Index of Diversity (Simpson 1949; Bowman et al. 2012) was used to define the community structure.

Simpson's Index of Diversity $=1-$ D:

$$
D=\frac{\sum \mathrm{n}(\mathrm{n}-1)}{\mathrm{N}(\mathrm{N}-1)}
$$

where $\mathrm{n}=$ total number of organisms of a particular species, and $\mathrm{N}=$ total number of organisms of all species.

\section{Nucleotide sequence accession numbers}

The partial 16S rRNA gene sequences in this study were deposited in the Genebank database under the accession numbers KT337506 to KT337538 and KT445946 to KT445948. A phylogenetic tree was constructed using the software, Molecular Evolutionary Genetics Analysis (MEGA) version 6.0.

\section{Screening of bacterial isolates for oil sludge degradability}

Preliminary screening with oil sludge

Bacteria isolates were screened for their ability to grow in oil sludge by sub-culturing on mineral salts agar that was laced with $1.5 \%$ crude oil sludge and incubated at $30{ }^{\circ} \mathrm{C}$ for 3-7 days (Wang et al. 2011; Liu et al. 2014). Pure colonies obtained were stored in nutrient agar slants at $4{ }^{\circ} \mathrm{C}$ for further screening and characterisation.

\section{Screening with 2,6-dichlorophenol indophenol}

Bacterial cultures were transferred from nutrient agar slants to test tubes containing Bushnell Haas broth and incubated for $24 \mathrm{~h}$ at $37^{\circ} \mathrm{C}$ at $180 \mathrm{rpm}$. A mixture of $0.5 \%$ (w/v) 2,6-dichlorophenol indophenol (2,6-DCPIP), 0.1\% Tween 80 and 3\% (v/v) crude oil sludge was then introduced into the tubes. The experiment was monitored daily for colour change from blue to colourless. The control experiment was prepared without 
inoculum and treatments were in duplicate (Hanson et al. 1993; Bidoia et al. 2010; Varjani et al. 2013; Ahirwar and Dehariya 2013). After 7 days of incubation at $28{ }^{\circ} \mathrm{C}$ under rotatory conditions and having observed the colour change, the liquid medium was filtered to separate the biomass. The filtrate was centrifuged at $8000 \mathrm{rpm}$ for $15 \mathrm{~min}$. The supernatant was then analysed at $609 \mathrm{~nm}$ using the ultra violet-visible (UV-VIS) spectrophotometer (Hach spectrophotometer DR 5000). The percentage of biodegradation was subsequently estimated as follows:

$$
\% \text { of degradation }=1-\frac{\text { Absorbance of treated sample }}{\text { Absorbance of control }} \times 100
$$

\section{Detection of catechol-2,3-dioxygenase genes in bacteria isolates}

Catechol-2,3-dioxygenase is an important extradiol dioxygenase in the metabolism of aromatic rings by soil bacteria (Broderick 1999; Kasuga et al. 2007). Colony PCR was subsequently performed on the bacteria isolates, and specific forward primer C230F (5'AAG AGG CAT GGG GGC GCA CCG GTT CGA-3') and reverse primer C230R (5'TCA CCA GCA AAC ACC TCG TTG CGG TTG CC-3') (Kasuga et al. 2007; Hesham Ael et al. 2014) were used to amplify the catechol-2,3-dioxygenase genes in a $20 \mu \mathrm{l} \mathrm{PCR}$ reaction. The cycling conditions were as follows: one cycle at $98{ }^{\circ} \mathrm{C}$ for $10 \mathrm{~s}$, followed by 34 cycles at $98{ }^{\circ} \mathrm{C}$ for one second, $55{ }^{\circ} \mathrm{C}$ for $1 \mathrm{~min}$ and $72{ }^{\circ} \mathrm{C}$ for $15 \mathrm{~s}$. A final extension step at $72{ }^{\circ} \mathrm{C}$ for $1 \mathrm{~min}$ was performed for one cycle. The PCR products were then examined in $1 \%$ agarose gel electrophoresis.

\section{Results}

\section{Isolation of bacteria}

After the enrichment cultivation, a total of 36 bacterial isolates were obtained from the compost samples and the control (oil sludge) (Table 1). Bacteria were also isolated from the control treatment that did not contain compost. The enrichment cultivation technique gave rise to bacteria isolates that were capable of resisting the toxicity of crude oil sludge while using it for their own carbon and energy requirements.

\section{Identification and characterisation of oil sludge degrading bacterial isolates}

The morphological characterisation and gram test reaction indicated the presence of 28 g-negative and 8 g-positive bacteria, of which bacilli formed $83.33 \%$ and cocobacilli and cocci represented 13.89 and $2.78 \%$ of the population respectively (Fig. 1). The phylum Proteobacteria was found to be the dominant species, representing about $77.78 \%$ of the population. Among the Proteobacteria, $\gamma$-proteobacteria $(39.38 \%)$ and $\beta$-proteobacteria (35.71\%) were the dominant class, while $\alpha$-proteobacteria formed the remaining $25 \%$. Firmicutes and actinobacteria represented 19.44 and $2.78 \%$ of the population, respectively.

\section{Molecular characterisation}

Colony PCR of the bacteria isolates gave amplicons of about 1465 base pairs in size. The presence of white bands signified the presence of the 16S rRNA genes in the amplified bacteria isolates. The negative control (Sabax sterile water) showed the absence of the genes as no bands was seen on the $1 \%$ agarose gel electrophoresis. 
Table 1 Morphological characterisation, gram reaction test results and molecular identification of bacteria isolates from compost

\begin{tabular}{|c|c|c|c|c|}
\hline $\begin{array}{l}\text { Bacteria isolates } \\
\text { ID }\end{array}$ & Shape of bacteria & $\begin{array}{l}\text { Gram reaction } \\
\text { test }\end{array}$ & $\begin{array}{l}\text { Molecular identification (most } \\
\text { likely identical taxonomic spe- } \\
\text { cies) }\end{array}$ & $\begin{array}{l}\text { Homology } \\
\text { (\%) }\end{array}$ \\
\hline S2C & Bacilli & - & Stenotrophomonas maltophilia & 99 \\
\hline S2E & Bacilli & - & Stenotrophomonas maltophilia & 99 \\
\hline S5A & Coccobacilli & - & Bordetella avium & 97 \\
\hline S5B & Coccobacilli & - & Brucella ceti & 99 \\
\hline $\mathrm{S} 5 \mathrm{C}$ & Coccobacilli & - & Bordetella avium & 98 \\
\hline S8D & Bacilli & + & Bacillus subtilis & 99 \\
\hline S11A & Bacilli & - & Pseudomonas denitificans & 98 \\
\hline $\mathrm{S} 11 \mathrm{E}$ & Bacilli & + & Bacillus subtilis & 100 \\
\hline $\mathrm{S} 11 \mathrm{~F}$ & Bacilli & + & Bacillus subtilis & 100 \\
\hline S14A & Bacilli & - & Achromobacter xylosoxidans & 99 \\
\hline S14C & Bacilli & - & Ochrobactrum anthropi & 99 \\
\hline S14D & Bacilli & - & Ochrobactrum anthropi & 99 \\
\hline S14D1 & Bacilli & - & Stenotrophomonas maltophilia & 97 \\
\hline S14E & Bacilli & - & Stenotrophomonas maltophilia & 97 \\
\hline SH17B & Cocci & - & Advenella kashmirensis & 94 \\
\hline $\mathrm{SH} 2 \mathrm{OA}$ & Baccilli & - & Ochrobactrum anthropi & 99 \\
\hline $\mathrm{SH} 2 \mathrm{OB}$ & Bacilli & - & Achromobacter xylosoxidans & 99 \\
\hline $\mathrm{SH} 23 \mathrm{~A}$ & Bacilli & + & Mycobacterium gilvum & 88 \\
\hline $\mathrm{SH} 23 \mathrm{~B}$ & Bacilli & - & Ochrobactrum anthropi & 99 \\
\hline $\mathrm{SH} 23 \mathrm{C}$ & Bacilli & - & Ochrobactrum anthropi & 99 \\
\hline $\mathrm{SH} 26 \mathrm{~A}$ & Bacilli & - & Pseudomonas denitrificans & 99 \\
\hline $\mathrm{SH} 26 \mathrm{~B}$ & Bacilli & - & Mesorhizobium opportunistrum & 97 \\
\hline $\mathrm{SH} 29 \mathrm{~B}$ & Bacilli & - & Achromobacter xylosoxidans & 99 \\
\hline $\mathrm{H} 35 \mathrm{~A}$ & Bacilli & - & Achromobacter xylosoxidans & 99 \\
\hline H35B & Bacilli & - & Ochrobactrum antropi & 98 \\
\hline $\mathrm{H} 35 \mathrm{C}$ & Bacilli & - & Pseudomonas denitrificans & 99 \\
\hline $\mathrm{H} 38 \mathrm{~A}$ & Bacilli & - & Psedomonas denitrificans & 99 \\
\hline $\mathrm{H} 38 \mathrm{C}$ & Bacilli & - & Klebsiella varricola & 82 \\
\hline $\mathrm{H} 41 \mathrm{C}$ & Bacilli & + & Bacillus subtilis & 99 \\
\hline H41D & Bacilli & + & Bacillus subtilis & 99 \\
\hline $\mathrm{H} 41 \mathrm{~F}$ & Bacilli & + & Bacillus subtilis & 99 \\
\hline $\mathrm{H} 41 \mathrm{H}$ & Bacilli & + & Bacillus subtilis & 99 \\
\hline H44B & Bacilli & - & Pseudomonas denitrificans & 99 \\
\hline Control A & Coccobacilli & - & Pusillimonas sp. & 95 \\
\hline Control B & Bacilli & - & Raoultella ornithinolytica & 99 \\
\hline Control D & Coccobacilli & - & Pusillimonas sp. & 95 \\
\hline
\end{tabular}

The analysis of the partial sequence of the 16S rRNA showed that the bacteria isolates belonged to the genera Stenotrophmonas, Pseudomonas, Bordetella, Brucella, Bacillus, Achromobacter, Ochrobactrum, Advenella, Mycobacterium, Mesorhizobium, Klebsiella, Pusillimonas and Raoultella.

The sequences of the bacteria isolates were used to generate operational taxonomic unit (OTU) to enable straightforward classifications.

The BLAST program identified species related to the nucleotides of the DNA sequences. Following the sequencing of the 16S rRNA genes, these sequences were 


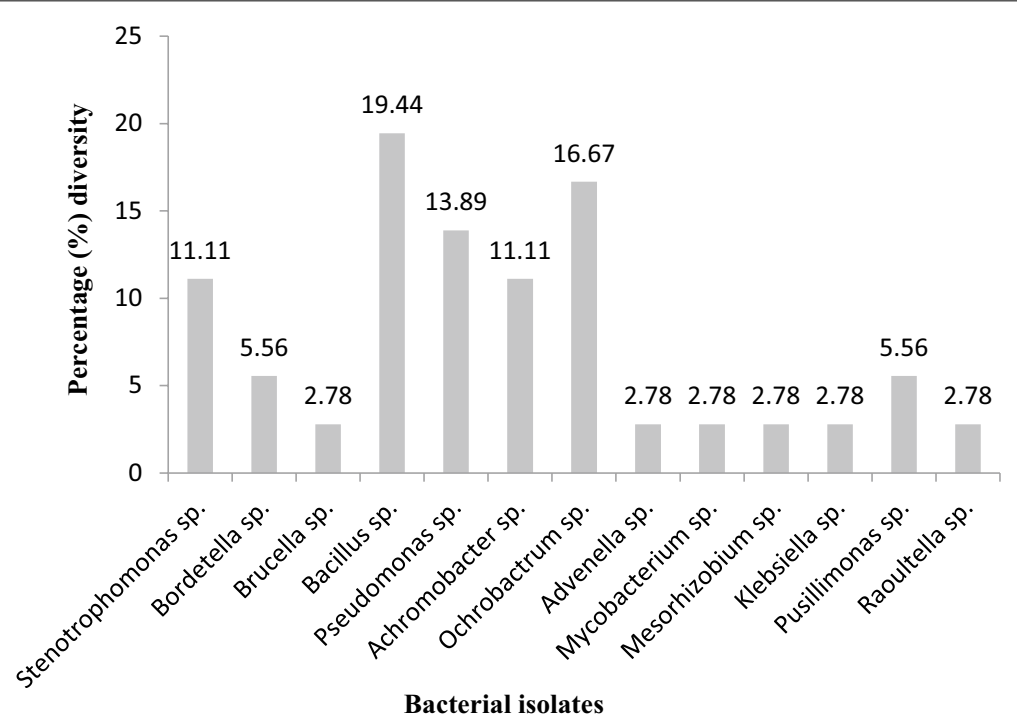

Fig. 1 Diversity percentage (\%) of the genus bacteria isolated in this study

grouped into thirteen OTUs with more than 95\% similarity following the sequencing of the (Table 2; Fig. 2). Bootstrap analysis with 1000 repetitions was performed and only values higher than $50 \%$ are shown.

Simpson's Index of Diversity (1-D) was calculated as 0.9; the greater the value of 1-D, the greater the sample diversity. On the other hand, Simpson's Index (D) was 0.1; the larger the value of $\mathrm{D}$, the lower the diversity. The distribution of microorganisms was found to be heterogeneous. The most dominant group of isolates, OTU 4 at genus level was closely related to Bacillus which represented about $19.44 \%$ of all the isolates. This was followed by OTU 5 and OTU 7 which represented about 13.89 and $16.67 \%$ of the population, respectively (Fig. 1; Table 2).

Table 2 Sequences, their OTU representatives and classifications

\begin{tabular}{lllll}
\hline OTUs & No. of sequences & OTU representatives & Phylum & Class \\
\hline OTU1 & 4 & Stenotrophomonas maltophilia & Proteobacteria & $\gamma$-proteobacteria \\
OTU2 & 2 & Bordetella avium & Proteobacteria & $\beta$-proteobacteria \\
OTU3 & 1 & Brucella ceti & Proteobacteria & $\beta$-proteobacteria \\
OTU4 & 7 & Bacillus subtilis & Firmicutes & Bacilli \\
OTU5 & 5 & Pseudomonas denitrificans & Proteobacteria & $\gamma$-proteobacteria \\
OTU6 & 4 & Achromobacter xylosoxidans & Proteobacteria & $\beta$-proteobacteria \\
OTU7 & 6 & Ochrobactrum anthropi & Proteobacteria & $\alpha$-proteobacteria \\
OTU8 & 1 & Advenella kashimirensis & Proteobacteria & $\beta$-proteobacteria \\
OTU9 & 1 & Mycobacterium gilvum & Actinobacteria & Actinobacteria \\
OTU10 & 1 & Mesorhizobium opportunistrum & Proteobacteria & $\alpha$-proteobacteria \\
OTU11 & 1 & Klebsiella varricola & Proteobacteria & $\gamma$-proteobacteria \\
OTU12 & 2 & Pusillimonas sp. & Proteobacteria & $\beta$-proteobacteria \\
OTU13 & 1 & Raoultella ornithinolytica & Proteobacteria & $\gamma$-proteobacteria \\
\hline
\end{tabular}




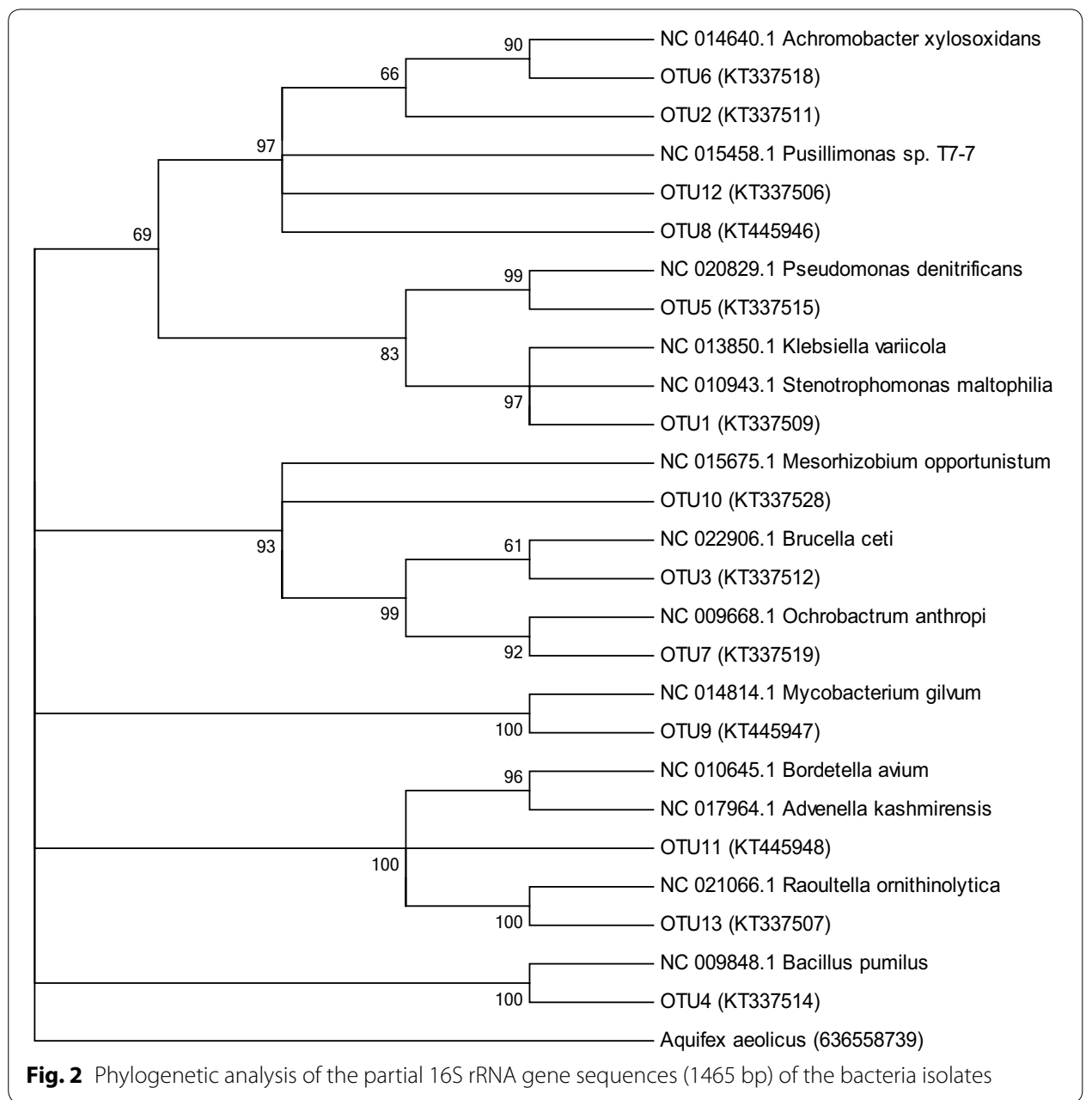

\section{Screening of bacterial isolates for oil sludge degradability}

The results showed that, after 7 days incubation all the bacteria isolates were able to grow on the mineral salts agar laced with crude oil sludge. This culture medium contained no carbon; the only source of carbon was the sterile crude oil sludge that was laced on the mineral salts agar plates.

Thirty-two of the 36 isolates showed a positive reaction to the indicator, 2,6-DCPIP. Pseudomonas sp. was identified as the best degrader (Fig. 3) as it was able to decolourise the 2,6-DCPIP in the shortest possible time. In addition, Pusillimonas, Achromobacter and Bacillus sp. were also among the top degraders.

\section{Detection of catechol-2,3-dioxygenae genes in bacteria isolates}

The presence of the cathecol-2,3-dioxygenase $(\mathrm{C} 23 \mathrm{O})$ genes was detected using the PCR technique with degenerate primers. The results showed that all the isolates possessed the $\mathrm{C} 23 \mathrm{O}$ genes. 


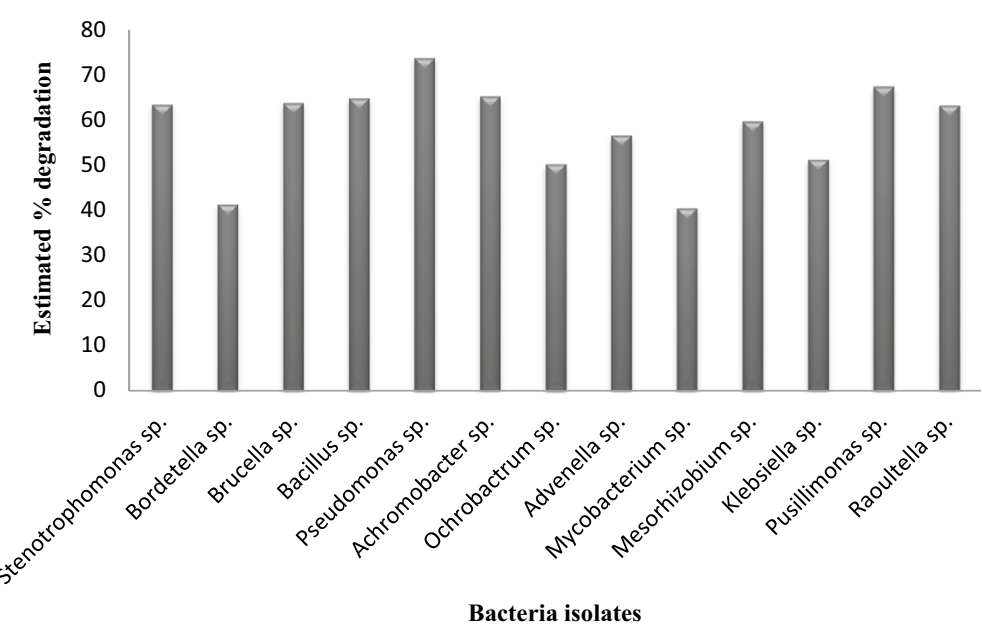

Fig. 3 Estimated percentage degradation rate of crude oil sludge by the bacteria isolates using 2,6-DCPIP

\section{Discussion}

The aim of this study was to isolate and characterise bacteria that are capable of using crude oil sludge for their carbon and energy requirements. This could be of further use in the bioaugmentation remediation process for crude oil sludge. According to the morphological characterisation and gram test reaction of the isolates (Table 1), composting of crude oil sludge gave rise to many bacteria isolates especially the gram-negative bacteria. Microbial degradation of oil sludge using gram-negative bacteria has been reported to improve the remediation of hydrocarbons (Zhang et al. 2011). The dominant species belong to the phylum Proteobacteria, which is comprised mainly of $\beta$-proteobacteria and $\gamma$-proteobacteria (Table 2). This result complies with the observations of Tan and Ji (2010) that these classes of bacteria possess the ability to use the nitrogen-sulphur-oxygen (NSO) fractions of crude oil sludge as their sources of nitrogen, carbon and energy.

According to our findings, organisms with PAH degrading ability belong to the genera Stenotrophmonas, Pseudomonas, Bordetella, Brucella, Bacillus, Achromobacter, Ochrobactrum, Advenella, Mycobacterium, Mesorhizobium, Klebsiella, Pusillimonas and Raoultella. This result is comparable to the findings of some studies (Hara et al. 2013; Molina et al. 2009; Mishra et al. 2014) that accentuated the abilities of most of the abovementioned isolates to use crude oil sludge for their carbon and energy requirements. Bacillus and Ochrobactrum formed the largest population with values of 19.44 and $16.67 \%$, respectively (Fig. 1). This could be due to their ability to proliferate more than other organisms in the presence of toxic organic material such as crude oil sludge.

Incorporating 2,6-DCPIP (an electron acceptor) in a culture medium made it possible to determine the capability of microorganisms to utilise substrate which in this study was crude oil sludge. The colour change of 2,6-DCPIP from blue (oxidised) to colourless (reduced) signified the utilisation of the crude oil sludge. This procedure was first applied in the biodegradation of oil in the method developed by Hanson et al. (1993). Among the assessed organisms, Pseudomonas sp. emerged as the best degrader with about a 73.7\% rate of biodegradation demonstrated by its rapid decolouration of the redox indicator (Fig. 3). Pusillimonas sp. and Achromobacter sp. also exhibited their potential in 
degrading crude oil sludge by changing the initial colour of the 2,6-DCPIP to colourless. Some reports have classified Pseudomonas and Bacillus genera as bio-emulsifiers with the potential to increase the bioavailability of PAHs for improved biodegradation ( $\mathrm{Yu}$ et al. 2007; Mishra et al. 2014). Many other bacteria species also have the potential to be good bioremediation agents as a result of their ability to degrade petroleum wastes and toxic organic solvents. For instance, genera such as Ochrobactrum, Bacillus, Pseudomonas, Advenella, Achromobacter and Stenotrophomonas have all been reported to play an active role in the biodegradation of crude oil sludge (Katsivela et al. 2005; Zhang et al. 2005; Veeranagouda et al. 2006; Rajaei et al. 2013; Santisi et al. 2015). These strains were able to use both aliphatic and aromatic hydrocarbons as their sole source of carbon and energy owing to their possession of the aromatic and aliphatic catabolic pathways (Rajaei et al. 2013). The inability of a few isolates to induce a colour change after 7 days of incubation did not really mean that they were unable to degrade crude oil sludge. Some of the isolates tend to be faster degraders than others, i.e. they change the colour of the indicator from blue to colourless within 7 days. Some environmental factors such as $\mathrm{pH}$ and temperature as well as the bioavailability of the oil sludge could be responsible for such an outcome (Karigar and Rao 2011). Based on this, a confirmatory test was also done using molecular tools to verify the presence of the catabolic genes in the bacteria isolates.

The aerobic metabolism of aromatic compounds results in the formation of three intermediates, namely catechol, protocatechuate and gentisic acid. These intermediates are further metabolised to forms in which they can be accessed by microorganisms such as simple acids and aldehydes (Mishra et al. 2014; Singh et al. 2013). The results of the assay of the cathecol-2,3-dioxygenase genes using a specific set of primers established that the bacteria isolates possessed these genes, which could be an indication that those bacteria also possess the catabolic abilities. This conforms to the findings of Mesarch et al. (2000) and Hara et al. (2013) that the presence of these genes in organisms can be an indication of their ability to degrade hydrophobic compounds. Accordingly, the presence of the catechol-2,3-dioxygenase genes in the bacteria isolates signifies the capability to degrade the crude oil sludge.

\section{Conclusion}

The capability of pure bacteria cultures to grow in and utilise crude oil sludge as their sole source of carbon and energy provides an environmentally friendly and economical process for dealing with such sludge. In view of the toxicity of crude oil sludge to humans and the environment, the isolation of pure bacteria cultures from compost mixtures for bioaugmentation purposes could be a step in the right direction. The inclusion of commercially available surfactants in our experiment encouraged the mass transfer of PAHs to the aqueous phase, thereby making them available for microorganisms to degrade.

\section{Abbreviations}

BLAST: Basic Local Alignment Search Tool; MEGA: molecular evolutionary genetics analysis; OTU: operational taxonomic unit; PAH: polycyclic aromatic hydrocarbon; UV-VIS: ultra violet-visible; 2,6-DCPIP: 2,6-dichlorophenol indophenol.

\section{Authors' contributions}

LO carried out the laboratory work and drafted the manuscript. The study was conceived by HA. RA and LO participated in the design of the experiment and revised the manuscript. All authors read and approved the final manuscript. 


\begin{abstract}
Author details
${ }^{1}$ Department of Environmental Sciences, University of South Africa, Johannesburg, South Africa. ${ }^{2}$ Institute for Science and Technology Education, University of South Africa, Pretoria, South Africa. ${ }^{3}$ Microbiology and Environmental Biotechnology Research Group, Agricultural Research Council - Institute for Soil, Climate and Water, Pretoria, South Africa. ${ }^{4}$ Unit for Environment Science and Management, North-West University (Potchefstroom Campus), Potchefstroom, South Africa.
\end{abstract}

\title{
Acknowledgements
}

All authors acknowledge the support received from the members of Microbiology and Environmental Biotechnology Research group, ARC-ISCW, Pretoria, South Africa.

\section{Competing interests}

The authors declare that they have no competing interests.

Availability of data and materials

DNA sequence data have been deposited in publicly available repository (NCBI website).

\section{Funding}

This work was supported by the University of South Africa (UNISA), the National Research Foundation (NRF) Thuthuka Grant Unique No. 84168, and the Agricultural Research Council, South Africa.

Received: 3 June 2016 Accepted: 28 October 2016

Published online: 09 November 2016

\section{References}

Ahirwar S, Dehariya K (2013) Isolation and characterization of hydrocarbon degrading microorganisms from petroleum oil contaminated soil sites. Bull Environ Sci Res 2(4):5-10

Antizar-Ladislao B, Lopez-Real J, Beck AJ (2006) Degradation of polycyclic aromatic hydrocarbons (PAHs) in an aged coal tar contaminated soil under in-vessel composting conditions. Environ Pollut 141(3):459-468. doi:10.1016/j. envpol.2005.08.066

Antizar-Ladislao B, Spanova K, Beck AJ, Russell NJ (2008) Microbial community structure changes during bioremediation of PAHs in an aged coal-tar contaminated soil by in-vessel composting. Int Biodeterior Biodegrad 61(4):357-364. doi:10.1016/j.ibiod.2007.10.002

Ayotamuno JM, Okparanma RN, Amadi F (2011) Enhanced remediation of an oily sludge with saline water. Afr J Environ SciTechnol 5(4):262-267

Badr El-Din SM, Moussa TA, Moawad H, Sharaf OA (2014) Isolation and characterization of polyaromatic hydrocarbons degrading bacteria from compost leachate. JAB 5(2):651-660

Balachandran C, Duraipandiyan V, Balakrishna K, Ignacimuthu S (2012) Petroleum and polycyclic aromatic hydrocarbons (PAHs) degradation and naphthalene metabolism in Streptomyces sp. (ERI-CPDA-1) isolated from oil contaminated soil. Bioresour Technol 112:83-90. doi:10.1016/j.biortech.2012.02.059

Bhattacharyya JK, Shekdar AV (2003) Treatment and disposal of refinery sludges: Indian scenario. Waste Manag Res 21(3):249-261. doi:10.1177/0734242X0302100309

Bidoia E, Montagnolli R, Lopes P (2010) Microbial biodegradation potential of hydrocarbons evaluated by colorimetric technique: a case study. Appl Microbiol Biotechnol 7:1277-1288

Bowman JS, Rasmussen S, Blom N, Deming JW, Rysgaard S, Sicheritz-Ponten T (2012) Microbial community structure of Arctic multiyear sea ice and surface seawater by 454 sequencing of the 16S RNA gene. ISME J 6(1):11-20. doi:10.1038/ismej.2011.76

Broderick JB (1999) Catechol dioxygenases. Essays Biochem 34:173-189

Bundy JG, Paton Gl, Campbell CD (2004) Combined microbial community level and single species biosensor responses to monitor recovery of oil polluted soil. Soil Biol Biochem 36(7):1149-1159. doi:10.1016/j.soilbio.2004.02.025

Cerqueira VS, Hollenbach EB, Maboni F, Vainstein MH, Camargo FA, do Carmo RPM, Bento FM (2011) Biodegradation potential of oily sludge by pure and mixed bacterial cultures. Bioresour Technol 102(23):11003-11010. doi:10.1016/j. biortech.2011.09.074

Chikere CB, Okpokwasili GC, Chikere BO (2011) Monitoring of microbial hydrocarbon remediation in the soil. 3 Biotech 1(3):117-138

Dean-Ross D, Moody J, Cerniglia CE (2002) Utilization of mixtures of polycyclic aromatic hydrocarbons by bacteria isolated from contaminated sediment. FEMS Microbiol Ecol 41(1):1-7. doi:10.1111/j.1574-6941.2002.tb00960x

Enabulele O, Obayagbona O (2013) Biodegradation potentials of mycoflora isolated from auto mobile workshop soils on flow station crude oil sludge. Int Res J Biol Sci 2(5):9-18

Garrity G, Brenner DJ, Krieg NR, Staley JT (2005) Bergey's manual of systematic bacteriology, 2nd edn. Springer, New York Hanson KG, Desai JD, Desai AJ (1993) A rapid and simple screening technique for potential crude oil degrading microorganisms. Biotechnol Tech 7(10):745-748. doi:10.1007/bf00152624

Hara E, Kurihara M, Nomura N, Nakajima T, Uchiyama H (2013) Bioremediation field trial of oil-contaminated soil with food-waste compost. J JSCE 1(1):125-132. doi:10.2208/journalofisce.1.1_125

Heidarzadeh N, Gitipour S, Abdoli MA (2010) Characterization of oily sludge from a Tehran oil refinery. Waste Manag Res 28(10):921-927. doi:10.1177/0734242X09345794

Hesham Ael L, Mawad AM, Mostafa YM, Shoreit A (2014) Biodegradation ability and catabolic genes of petroleumdegrading Sphingomonas koreensis strain ASU-06 isolated from Egyptian oily soil. Biomed Res Int 2014:127674. doi:10.1155/2014/127674 
Karigar CS, Rao SS (2011) Role of microbial enzymes in the bioremediation of pollutants: a review. Enzyme Res 2011:805187. doi:10.4061/2011/805187

Kasuga I, Nakajima F, Furumai H (2007) Diversity of catechol 2,3-dioxygenase genes of bacteria responding to dissolved organic matter derived from different sources in a eutrophic lake. FEMS Microbiol Ecol 61(3):449-458. doi:10.1111/j.1574-6941.2007.00347.x

Katsivela E, Moore ER, Maroukli D, Strömpl C, Pieper D, Kalogerakis N (2005) Bacterial community dynamics during in situ bioremediation of petroleum waste sludge in landfarming sites. Biodegradation 16(2):169-180. doi:10.1007/ s10532-004-4883-y

Liu YC, Li LZ, Wu Y, Tian W, Zhang LP, Xu L, Shen QR, Shen B (2010) Isolation of an alkane-degrading Alcanivorax sp. strain 2B5 and cloning of the alkB gene. Bioresour Technol 101(1):310-316. doi:10.1016/j.biortech.2009.08.028

Liu H, Yao J, Yuan Z, Shang Y, Chen H, Wang F, Masakorala K, Yu C, Cai M, Blake RE, Choi MMF (2014) Isolation and characterization of crude-oil-degrading bacteria from oil-water mixture in Dagang oilfield, China. Int Biodeterior Biodegrad 87:52-59. doi:10.1016/j.ibiod.2013.11.005

Loick N, Hobbs PJ, Hale MDC, Jones DL (2009) Bioremediation of poly-aromatic hydrocarbon (PAH)-contaminated soil by composting. Crit Rev Environ Sci Technol 39(4):271-332. doi:10.1080/10643380701413682

Maiti A, Das S, Bhattacharyya N (2012) Isolation and characterization of a new bacterial strain from petroleum oil contaminated soil, India. J Sci 2:103-108

Mesarch MB, Nakatsu CH, Nies L (2000) Development of catechol 2,3-dioxygenase-specific primers for monitoring bioremediation by competitive quantitative PCR. Appl Environ Microbiol 66(2):678-683. doi:10.1128/ aem.66.2.678-683.2000

Milic J, Beskoski V, llic M, Ali S, Gojgic-Cvijovic G, Vrvic M (2009) Bioremediation of soil heavily contaminated with crude oil and its products: composition of the microbial consortium. J Serb Chem Soc 74(4):455-460. doi:10.2298/ jsc0904455m

Mishra S, Singh SN, Pande V (2014) Bacteria induced degradation of fluoranthene in minimal salt medium mediated by catabolic enzymes in vitro condition. Bioresour Technol 164:299-308. doi:10.1016/j.biortech.2014.04.076

Molina MC, Gonzalez N, Bautista LF, Sanz R, Simarro R, Sanchez I, Sanz JL (2009) Isolation and genetic identification of PAH degrading bacteria from a microbial consortium. Biodegradation 20(6):789-800. doi:10.1007/s10532-009-9267-X

Niti C, Sunita S, Kamlesh K, Rakesh K (2013) Bioremediation: an emerging technology for remediation of pesticides. Res J Chem Environ 17:88-105

Panda S, Kar R, Panda C (2013) Isolation and identification of petroleum hydrocarbon degrading microorganisms from oil contaminated environment. Int J Environ Sci Technol 3(5):1314-1321

Rajaei S, Seyedi SM, Raiesi F, Shiran B, Raheb J (2013) Characterization and potentials of indigenous oil-degrading bacteria inhabiting the rhizosphere of Wild Oat (Avena Fatua L.) in South West of Iran. Iran J Biotechnol 11(1):32-40. doi:10.5812/ijb.9334

Riser-Roberts E (1992) Bioremediation of petroleum contaminated sites. CK Smoley, Boca Raton

Santisi S, Cappello S, Catalfamo M, Mancini G, Hassanshahian M, Genovese L, Giuliano L, Yakimov MM (2015) Biodegradation of crude oil by individual bacterial strains and a mixed bacterial consortium. Braz J Microbiol 46(2):377-387. doi:10.1590/S1517-838246120131276

Sayara T, Borràs E, Caminal G, Sarrà M, Sánchez A (2011) Bioremediation of PAHs-contaminated soil through composting: influence of bioaugmentation and biostimulation on contaminant biodegradation. Int Biodeterior Biodegrad 65(6):859-865. doi:10.1016/j.jibiod.2011.05.006

Simpson EH (1949) Measurement of diversity. Nature 163(4148):688. doi:10.1038/163688a0

Singh K, Chandra S (2014) Treatment of petroleum hydrocarbon polluted environment through bioremediation: a review. Pak J Biol Sci 17(1):1-8. doi:10.3923/pjbs.2014.1.8

Singh SN, Kumari B, Upadhyay SK, Mishra S, Kumar D (2013) Bacterial degradation of pyrene in minimal salt medium mediated by catechol dioxygenases: enzyme purification and molecular size determination. Bioresour Technol 133:293-300. doi:10.1016/j.biortech.2013.01.068

Tan Y, Ji G (2010) Bacterial community structure and dominant bacteria in activated sludge from a $70^{\circ} \mathrm{C}$ ultrasoundenhanced anaerobic reactor for treating carbazole-containing wastewater. Bioresour Technol 101(1):174-180. doi:10.1016/j.biortech.2009.08.044

Varjani SJ, Rana DP, Bateja S, Upasani VN (2013) Original research article isolation and screening for hydrocarbon utilizing bacteria (HUB) from petroleum samples. Int J Curr Microbiol Appl Sci 2(4):48-60. doi:10.1007/bf03326219

Veeranagouda Y, Emmanuel Paul PV, Gorla P, Siddavattam D, Karegoudar TB (2006) Complete mineralisation of dimethylformamide by Ochrobactrum sp. DGVK1 isolated from the soil samples collected from the coalmine leftovers. Appl Microbiol Biotechnol 71(3):369-375. doi:10.1007/s00253-005-0157-9

Wang XB, Chi CQ, Nie Y, Tang YQ, Tan Y, Wu G, Wu XL (2011) Degradation of petroleum hydrocarbons (C6-C40) and crude oil by a novel Dietzia strain. Bioresour Technol 102(17):7755-7761. doi:10.1016/j.biortech.2011.06.009

Wong JWC, Fang M, Zhao Z, Xing B (2004) Effect of Surfactants on solubilization and degradation of phenanthrene under thermophilic conditions. J Environ Qual 33(6):2015. doi:10.2134/jeq2004.2015

Wu Y, Luo Y, Zou D, Ni J, Liu W, Teng Y, Li Z (2008) Bioremediation of polycyclic aromatic hydrocarbons contaminated soil with Monilinia sp.: degradation and microbial community analysis. Biodegradation 19(2):247-257. doi:10.1007/ s10532-007-9131-9

Wyrwas B, Chrzanowski L, Lawniczak L, Szulc A, Cyplik P, Bialas W, Szymanski A, Holderna-Odachowska A (2011) Utilization of Triton X-100 and polyethylene glycols during surfactant-mediated biodegradation of diesel fuel. J Hazard Mater 197:97-103. doi:10.1016/j.jhazmat.2011.09.060

Yu H, Zhu L, Zhou W (2007) Enhanced desorption and biodegradation of phenanthrene in soil-water systems with the presence of anionic-nonionic mixed surfactants. J Hazard Mater 142(1-2):354-361. doi:10.1016/j. jhazmat.2006.08.028

Zhang R, Cui Z, Jiang J, He J, Gu X, Li S (2005) Diversity of organophosphorus pesticide-degrading bacteria in a polluted soil and conservation of their organophosphorus hydrolase genes. Can J Microbiol 51(4):337-343. doi:10.1139/w05-010 
Zhang SY, Wang QF, Xie SG (2011) Microbial community changes in contaminated soils in response to phenanthrene amendment. IJEST 8(2):321-330. doi:10.1007/bf03326219

Submit your manuscript to a SpringerOpen ${ }^{\circ}$ journal and benefit from:

- Convenient online submission

- Rigorous peer review

- Immediate publication on acceptance

- Open access: articles freely available online

- High visibility within the field

- Retaining the copyright to your article

Submit your next manuscript at $\boldsymbol{\nabla}$ springeropen.com 